\title{
Vasorelaxant and Hypotensive Effects of Tilisolol Hydrochloride (N-696) in Isolated Rat Thoracic Aorta and Pithed Rats
}

\author{
Toshiji Sugai, Kazuko Kojima, Naomi Iwakami and Yoshikuni Suzuki \\ Biological Research Laboratory, Pharmaceutical Research Center, Nisshin Flour Milling Co., Ltd., \\ 5-3-1, Tsurugaoka, Ohi-Machi, Iruma-gun, Sairama 354, Japan \\ Received April 15, 1991 Accepted August 2, 1991
}

\begin{abstract}
Vasorelaxant and hypotensive effects of tilisolol hydrochloride (N-696) in isolated rat thoracic aorta and pithed rats were investigated. In rat thoracic aorta pre-contracted with $\mathrm{KCl}(20 \mathrm{mM})$, tilisolol $\left(10^{-5}-10^{-3} \mathrm{M}\right)$ produced concentration-related relaxation, but nadolol and atenolol did not significantly inhibit the responses to $20 \mathrm{mM} \mathrm{KCl}$. The concentration-relaxation curve of tilisolol underwent rightward parallel shifts only to a limited extent in the presence of glibenclamide, a specific antagonist of $\mathrm{K}^{-}$channel openers. Glibenclamide also shifted the concentration-relaxation curve of cromakalim to the right and in a parallel manner, whereas it did not change that of propranolol. In pithed rats, tilisolol $(0.5-2.0 \mathrm{mg} / \mathrm{kg}, \mathrm{i} . \mathrm{v}$.$) , but neither nadolol$ nor atenolol, caused a dose-dependent decrease in diastolic blood pressure and a slight increase in heart rate. Following treatment of the preparation with glibenclamide, the hypotensive effects of tilisolol and cromakalim were antagonized, while that of propranolol was not affected. These results suggest that the vasorelaxant and hypotensive actions of tilisolol involve an opening of $\mathrm{K}^{+}$channels which can be inhibited by glibenclamide and may also involve additional relaxant mechanisms of action independent of $\mathrm{K}^{+}$channel opening.
\end{abstract}

$\beta$-Adrenoceptor antagonists ( $\beta$-blockers) differ from one another in potency, cardioselectivity, intrinsic sympathomimetic activity (ISA), membrane stabilizing action (MSA), and duration of action (1). In addition to the $\beta$ blocking activity, some of the recently developed $\beta$-blockers have other pharmacological activities (2). Tilisolol hydrochloride $(\mathrm{N}-696)$ is a long acting $\beta$-adrenoceptor blocking agent that also possesses vasodilator properties (3, $4)$. The pharmacological profile of tilisolol as a $\beta$-blocker is very similar to that of nadolol, namely, tilisolol is not cardioselective and has no ISA or MSA. The duration of the $\beta$-adrenoceptor blocking action of tilisolol in $\operatorname{dogs}$ is about five times longer than that of propranolol (3). In human studies, there is some evidence that tilisolol may have direct vasodilator action $(5,6)$; however, the mechanism by which tilisolol exerts its vasodilator action remains to be clucidated. It was the aim of the present study to confirm the vasodilator action of tilisolol and to investigate its mechanism. We compared the effects of tilisolol with those of nadolol and atcnolol in isolated rat aorta and in adrenalectomized pithed rats; we also compared its effects with those of propranolol, a very widely used $\beta$-adrenoceptor antagonist.

Recently, a new class of direct-acting vasodilators, called $\mathrm{K}^{+}$channel openers, has been 
developed (7). Cromakalim is thought to produce vasodilator action by opening $\mathrm{K}^{+}$channels in the plasma membrane of smooth muscle cells $(8-10)$. More recently, it has been shown that glibenclamide, an oral antidiabetic drug, antagonized the vasodilator effect of cromakalim in vitro and in vivo $(11-13)$. To examine the possible vasodilating mechanisms of tilisolol, we compared the effects of tilisolol and cromakalim in isolated rat aorta and in pithed rats. Wc also investigated whether the vasodilator effect of tilisolol was antagonized by glibenclamide in these preparations.

\section{MATERIALS AND METHODS}

\section{Isolated rat thoracic aorta}

Malc Spraguc-Dawley rats $(270-525 \mathrm{~g})$ were anesthetized with ether and killed by bleeding from carotid arteries. The thoracic aorta was removed rapidly and placed in a 10$\mathrm{ml}$ tissue bath containing modificd Krebs solution of the following composition: $112 \mathrm{mM}$ $\mathrm{NaCl}, 5 \mathrm{mM} \mathrm{KCl}, 1.25 \mathrm{mM} \mathrm{CaCl}, 1.2 \mathrm{mM}$ $\mathrm{MgSO}_{4}, 1.0 \mathrm{mM} \mathrm{KH} \mathrm{PO}_{4}, 25 \mathrm{mM} \mathrm{NaHCO}$, and $11.5 \mathrm{mM}$ D-glucose. No attempt was made to remove the vascular endothelium. The bathing solution was warmed to $37^{\circ} \mathrm{C}$ and gassed with $95 \% \mathrm{O}_{2}+5 \% \mathrm{CO}_{2}$. The contractile tension of the preparation was measured isometrically with a force displacement transducer (Nihon Kohden, TB-612T) and recorded on a multichannel recorder (MT Giken, TI104).

In the first series of experiments, helical strips ( $3 \mathrm{~mm}$ wide, $30 \mathrm{~mm}$ length) were prepared. Following an equilibration period of 60 $\min , \mathrm{KCl}$ was added to the bathing solution at a concentration ranging from $5-100 \mathrm{mM}$, and cumulative concentration-response curves for $\mathrm{KCl}$ were constructed. Tissues were then washed and allowed to relax to baseline (40$50 \mathrm{~min})$; test drugs under investigation were added to the bath; and 30 min later, the cumulative concentration-response curves for $\mathrm{KCl}$ were repeated. Tissues were washed again and allowed to relax to baseline; and after a 30 -min incubation period with test drugs, another set of cumulative concentration-response curves were constructed. The effects in the presence of test drugs were expressed as percentages of the preceding maximum response to $\mathrm{KCl}(=100 \%)$ for each tissue.

In a sccond series of experiments, aortic rings, $2-3 \mathrm{~mm}$ wide, were prepared. Following an equilibration period of $60 \mathrm{~min}, 20 \mathrm{mM}$ $\mathrm{KCl}$ was added to each bath. The magnitude of the $20 \mathrm{mM} \mathrm{KCl}$-induced contraction was about $95 \%$ of the maximum contraction developed by $100 \mathrm{mM} \mathrm{KCl}$ in these tissues. After the tissue contractions were allowed to reach a plateau $(20-30 \mathrm{~min})$, the tested drugs were added to the preparations in half $\log$ unit increments. The effects of the vasorelaxant drugs were expressed as the \% decrease in the tension produced by $20 \mathrm{mM} \mathrm{KCl}$.

When consecutive additions of the drugs produced no further relaxation, the tissues were washed with modified Krebs solution every $10 \mathrm{~min}$ over a $60-\mathrm{min}$ period. To contract the tissue, $20 \mathrm{mM} \mathrm{KCl}$ was added once more; and when a platcau was reached, glibenclamide or vehicle was added and allowed to equilibrate for $15 \mathrm{~min}$. Once the tension had restablized, the tissues were rechallenged with the same vasorclaxant drugs as before.

\section{Pithed rats}

Male Wistar rats $(230-330 \mathrm{~g})$ were anesthetized by intraperitoncal administration of sodium thiopental $(50-60 \mathrm{mg} / \mathrm{kg})$ and then bilaterally adrenalectomized via retroperitoneal incision. The tracheas were cannulated, and the animals were subjected to artificial respiration $(50 / \mathrm{min}$, tidal volume $1.0 \mathrm{ml} / 100 \mathrm{~g})$ by means of an animal respirator (Harvard, model 680) with room air $\mathrm{O}_{2}$ supplement. Arterial blood pressure was measured from the right carotid artery via a pressure transducer (Gould, T4812D), and heart rate was monitored with a cardiotachometr (Nihon Kohden, AT- $600 \mathrm{G}$ ) triggered by the arterial pulse pressure. The left femoral vein was cannulated for intravenous administration of drugs. Drugs were administered in a volume of $0.5 \mathrm{ml} / \mathrm{kg}$. The animals were atropinized 
with $1 \mathrm{mg} / \mathrm{kg}$, i.v. of atropinc and pithed by the method of Gillespie et al. (14). Contraction of skeletal muscles was prevented by pretreatment with d-tubocurarine $(1 \mathrm{mg} / \mathrm{kg}$, i.v. $)$. The preparation was allowed to equilibrate for at least $30 \mathrm{~min}$ before the test drug was administered.

\section{Drugs}

Tilisolol hydrochloride and propranolol hydrochloride were synthesized in our laboratory. Glibenclamide and nadolol (Sigma), cromakalim (Maybridge), atenolol hydrochloride (Sterochim), atropine sulfate (Wako), and d-tubocurarine (Amerizole, Yoshitomi) were purchased from the respective companies. For the in vitro studies, nadolol was dissolved in distilled water containing equimolar succinic acid to make a stock solution of $2 \times 10{ }^{2} \mathrm{M}$, which was then further diluted with distilled water before use. Glibenclamide and cromakalim were dissolved in dimethylformamide and $10 \%$ $\mathrm{v} / \mathrm{v}$ ethyl alcohol/polyethylene glycol 400 , respectively, to make stock solutions of $2 \times 10^{3}$ $M$, which were then diluted with distilled water before use. For the in vivo study, nadolol $(6 \mathrm{mg} / \mathrm{ml})$ was dissolved in $0.9 \%$ saline containing equimolar succinic acid and diluted with $0.9 \%$ saline to the desired concentration. Glibenclamide $(20 \mathrm{mg} / \mathrm{ml})$ and cromakalim (1 $\mathrm{mg} / \mathrm{ml}$ ) were dissolved in $75 \% \mathrm{v} / \mathrm{v}$ dimethylformamide $/ 0.9 \%$ saline and $50 \% \mathrm{v} / \mathrm{v}$ ethyl alcohol / polyethylene glycol 400 , respectively, and diluted with $0.9 \%$ saline to the desired concentration. Tilisolol, propranolol, atenolol, and atropine were dissolved in distilled water for the in vitro studies and in $0.9 \%$ saline for the in vivo studies.

\section{Statistics}

The values are expressed as the mean \pm S.E. in both the text and Figures. Statistical significance, which was determined by Student's $t$-test or the paired $t$-test, is indicated by ${ }^{*} \mathrm{P}<0.05,{ }^{* *} \mathrm{P}<0.01$, or ${ }^{* * *} \mathrm{P}<0.001$.

\section{RESULTS}

\section{Isolated rat thoracic aorta}

In the rat aortic strips, the cumulative concentration-response curves for $\mathrm{KCl}(5-100$ $\mathrm{mM}$ ) were not affected by the treatment with vehicle (data not shown), while tilisolol $\left(10^{-4}\right.$ $M)$ produced a relaxant effect like that produced by cromakalim $\left(3 \times 10^{-7} \mathrm{M}\right)$ (Fig. 1). The characteristic profile of the relaxant effect
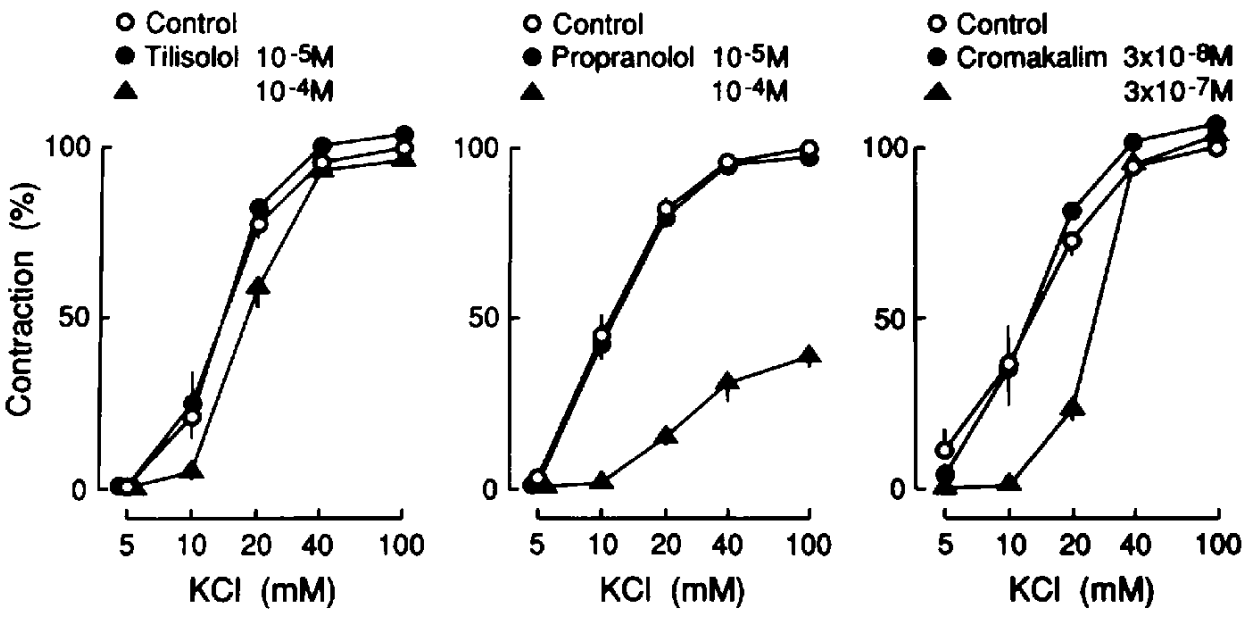

Fig. 1. Effects of tilisolol, propranolol and cromakalim on $\mathrm{KCl}$-induced contraction of rat thoracic aorta. Each point represents the mean \pm S.E. of 4 experiments. 
of tilisolol and cromakalim was the rightward shift of the concentration-response curves for $\mathrm{KCl}$ and a selective inhibition against responses to low concentrations of $\mathrm{KCl}(10-20$ $\mathrm{mM})$. In contrast, propranolol $\left(10^{-4} \mathrm{M}\right)$ caused a suppression of the maximum response to $\mathrm{KCl}$ with the characteristics of noncompetitive inhibition (Fig. 1).

In the rat aortic rings, we examined the effects of tilisolol, cromakalim, and other $\beta$ adrenoceptor blocking agents on the sustained contraction elicited by $20 \mathrm{mM} \mathrm{KCl}$. The cumulative application of tilisolol $\left(10^{-5}-10^{3}\right.$ M), propranolol $\left(10^{-5}-3 \times 10^{-4} \mathrm{M}\right)$, and cromakalim $\left(10^{-8}-3 \times 10^{-6} \mathrm{M}\right)$ inhibited this contraction in a concentration-dependent manner, while nadolol $\left(10^{-6}-3 \times 10^{4} \mathrm{M}\right) \mathrm{did}$ not produce any significant inhibition of response to $20 \mathrm{mM} \mathrm{KCl}$. Converscly, atenolol $\left(10^{5}-3 \times 10^{-4} \mathrm{M}\right)$ produced a further contraction of the tonic contractile response to 20 $\mathrm{mM} \mathrm{KCl}$. The maximum contraction $(3 \times$

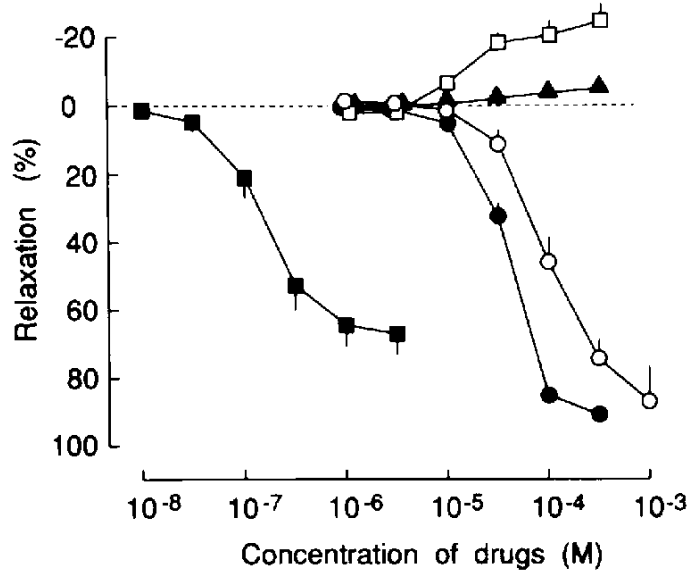

Fig. 2. Relaxant effects of $\beta$-adrenoceptor antagonists and cromakalim against rat thoracic aorta precontracted with $20 \mathrm{mM} \mathrm{KCl}$. Each point represents the mean \pm S.E. of 4 experiments. $O$ : tilisolol, 0 : propranolol, $\mathbf{\Delta}$ : nadolol, []: atenolol, $\mathbf{\square}$ : cromakalim. (a)

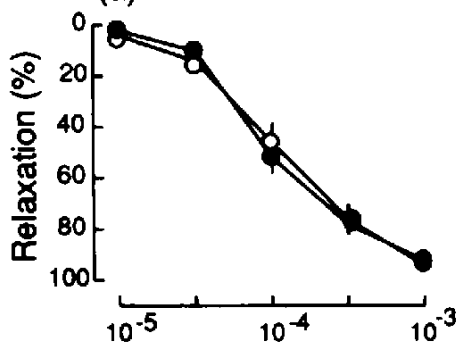

(c)

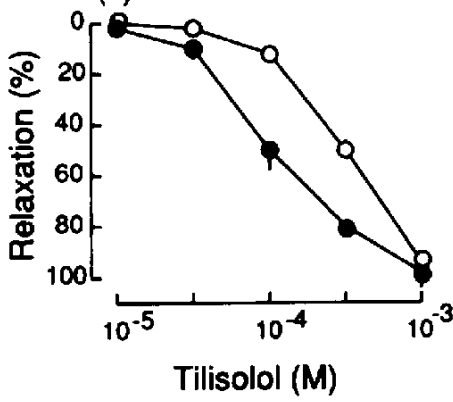

(b)

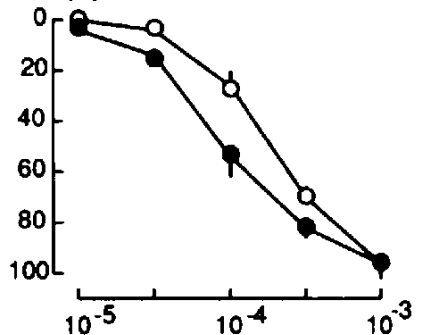

(d)

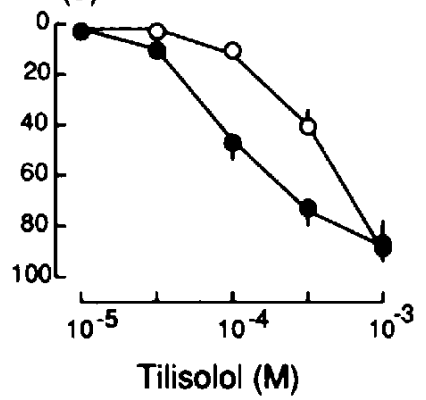

Fig. 3. Effects of glibenclamide on the relaxant action of tilisolol in rat thoracic aorta precontracted with $20 \mathrm{mM} \mathrm{KCl}$. The effects of glibenclamide at $10^{--7} \mathrm{M}(\mathrm{b}), 3 \times 10^{-7} \mathrm{M}(\mathrm{c})$, and $10^{6}{ }^{6} \mathrm{M}(\mathrm{d})$ are compared with the solvent control (a). Each point represents the mean \pm S.E. of 4 experiments. $O$ : control, $O$ : glibenclamide. 


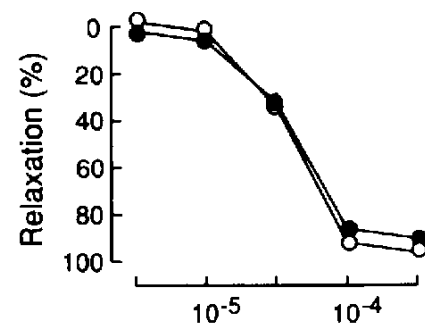

Propranolol (M)

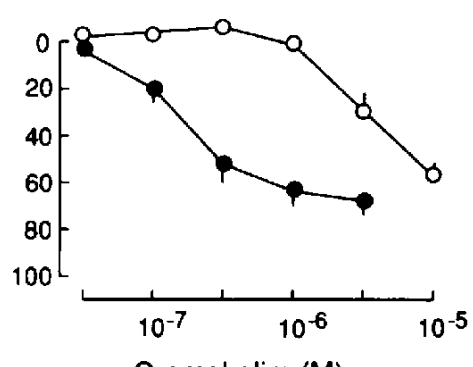

Cromakalim (M)

Fig. 4. Effects of glibenclamide $\left(10^{6} \mathrm{M}\right)$ on the relaxant action of propranolol and cromakalim in rat thoracic aorta precontracted with $20 \mathrm{mM} \mathrm{KCl}$. Each point represents the mean $\pm \mathrm{S}$. E. of 4 experiments. : control, 0 : glibenclamide.

$10^{-4} \mathrm{M}$ ) of atenolol was $24.5 \pm 4.9 \%$ (Fig. 2). With tilisolol and propranolol, the relaxation was nearly complete at their maximum effects; However, with cromakalim, relaxation remained about $70.5 \%$ even at its maximum effect. The $\mathrm{IC}_{50}$ values calculated from the $50 \%$ decrease in contractile force elicited by $20 \mathrm{mM} \mathrm{KCl}$ were $1.3 \pm 0.3 \times 10^{-4} \mathrm{M}$ (tilisolol), $4.5 \pm 0.3 \times 10^{-5} \mathrm{M}$ (propranolol), and $3.6 \pm 1.1 \times 10^{-7} \mathrm{M}$ (cromakalim), respectively.

Pretreatment of tissues for $15 \mathrm{~min}$ with glibenclamide $\left(10^{-7}-3 \times 10^{-7} \mathrm{M}\right)$ produced paralled shifts to the right of the tilisolol concentration-response curve. However, a further increase in concentrations of glibenclamide to $10^{6} \mathrm{M}$ failed to produce a further rightward shift of the curves. The concentration ratios of tilisolol calculated on the basis of its $I_{50}$ values were $2.0,3.2$ and 3.5 , respectively (Fig. 3). Glibenclamide $\left(10^{-6} \mathrm{M}\right)$ also produced paralled shifts to the right of the relaxant responses to cromakalim, whereas the propranolol concentration-response curve was not affected (Fig. 4).

\section{Pithed rats}

Intravenous administration of tilisolol (0.5$2.0 \mathrm{mg} / \mathrm{kg}$ ) to pithed rats caused a dosc-dependent decrease in diastolic pressure and a slight increase in heart rate (Fig. 5), but diastolic blood pressure and heart rate were not changed by intravenous administration of
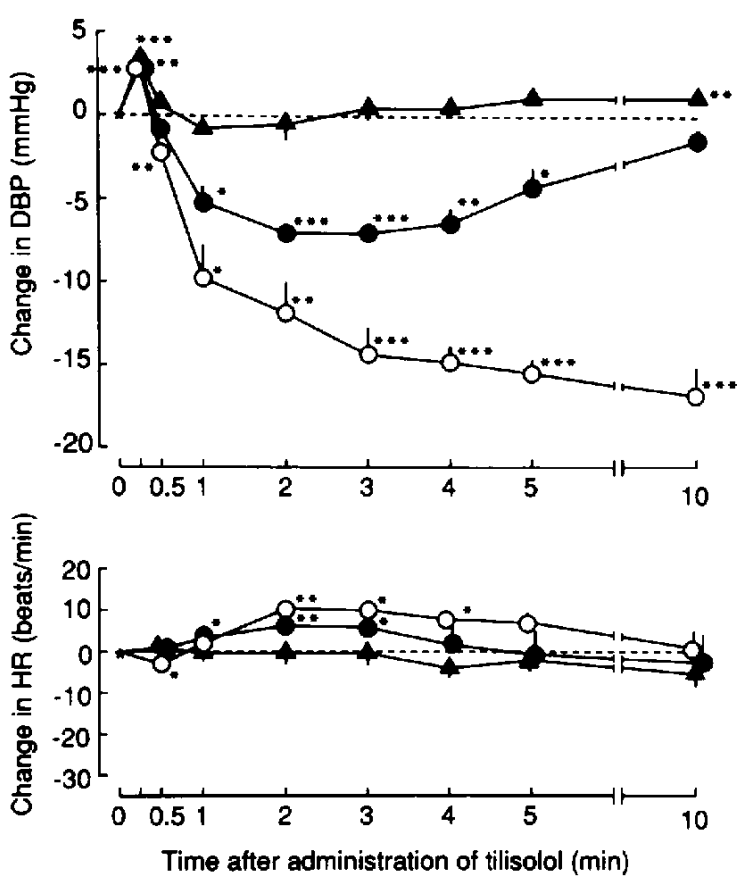

Fig. 5. Effects of i.v. administration of tilisolol (0.5 $\mathrm{mg} / \mathrm{kg}, \mathbf{A} ; 1.0 \mathrm{mg} / \mathrm{kg}, \quad ; 2.1 \mathrm{mg} / \mathrm{kg}, 0)$ on the diastolic blood pressure (DBP) and heart rate (HR) of pithed rats. Initial DBP values were $47.2 \pm 2.1(0.5$ $\mathrm{mg} / \mathrm{kg}), \quad 49.1 \pm 2.1 \quad(1.0 \mathrm{mg} / \mathrm{kg})$, and $48.1 \pm 3.0$ $\mathrm{mmHg}(2.0 \mathrm{mg} / \mathrm{kg})$. Corresponding HR values were $338 \pm 13,324 \pm 2$, and $317 \pm 7$ beats $/ \mathrm{min}$, respectively. Each point represents the mean \pm S.E. of $4-5$ experiments. ${ }^{*} \mathrm{P}<0.05,{ }^{* *} \mathrm{P}<0.01,{ }^{* * *} \mathrm{P}<0.001$. 
nadolol $(1.0 \mathrm{mg} / \mathrm{kg})$ or atenolol $(1.0 \mathrm{mg} / \mathrm{kg})$. Intravenous administration of propranolol (1.0 $\mathrm{mg} / \mathrm{kg}$ ) resulted in an initial rapid fall of diastolic blood pressure, associated with a definite decrease in heart rate. Intravenous administration of cromakalim $(0.01 \mathrm{mg} / \mathrm{kg})$ to pithed rats caused a decrease in diastolic pressure, but heart rate did not change (Fig. 6). The hypotensive activity of tilisolol (1.0 $\mathrm{mg} / \mathrm{kg}$, i.v.) was similar to that of cromakalim $(0.01 \mathrm{mg} / \mathrm{kg}$, i.v. $)$.

In a subsequent experiment, the influences of intravenously administered glibenclamide on the hypotensive responses to tilisolol, propranolol and cromakalim were studied. Glibenclamide was dissolved in $75 \%$ dimcthylformamide (DMF). Administration of
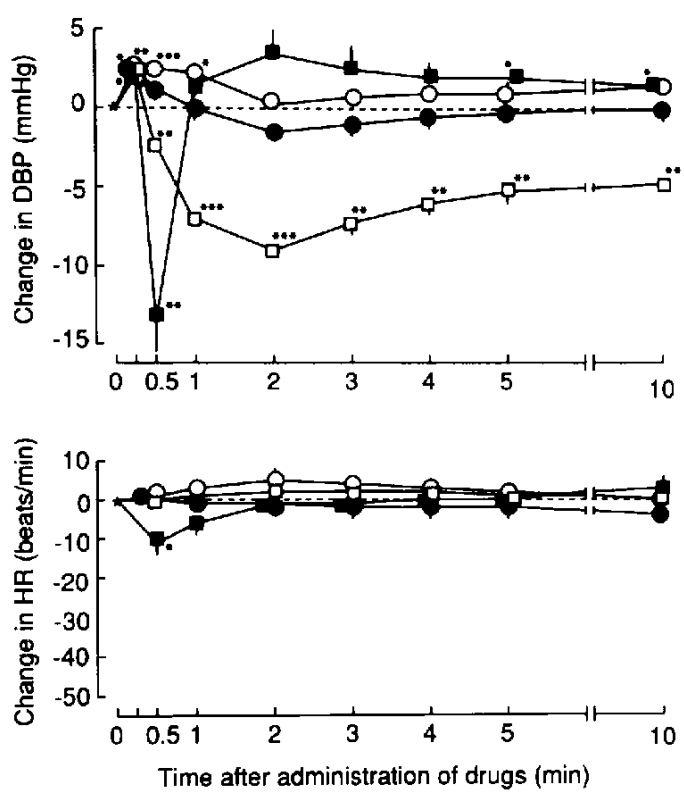

Fig. 6. Effects of i.v. administration of nadolol (1.0 $\mathrm{mg} / \mathrm{kg}, \bigcirc)$, atenolol $(1.0 \mathrm{mg} / \mathrm{kg}, \bigcirc)$, propranolol (1.0 $\mathrm{mg} / \mathrm{kg}, \square)$, and cromakalim $(0.01 \mathrm{mg} / \mathrm{kg}, \square)$ on the diastolic blood pressure (DPP) and heart rate (HR) of pithed rats. Initial DBP values were $48.4 \pm 1.4$ (nadolol), $48.9 \pm 2.4$ (atenolol), $50.1 \pm 2.1$ (propranolol), and $51.3 \pm 2.0 \mathrm{mmHg}$ (cromakalim). Corresponding HR values were $339 \pm 14,320 \pm 8,306 \pm 15$, and 325 \pm 4 bcats $/ \mathrm{min}$, respectively. Each point represents the mean \pm S.E. of $4-5$ experiments. ${ }^{*} \mathrm{P}<0.05,{ }^{* *} \mathrm{P}<$ $0.01,{ }^{* * *} \mathrm{P}<0.001$
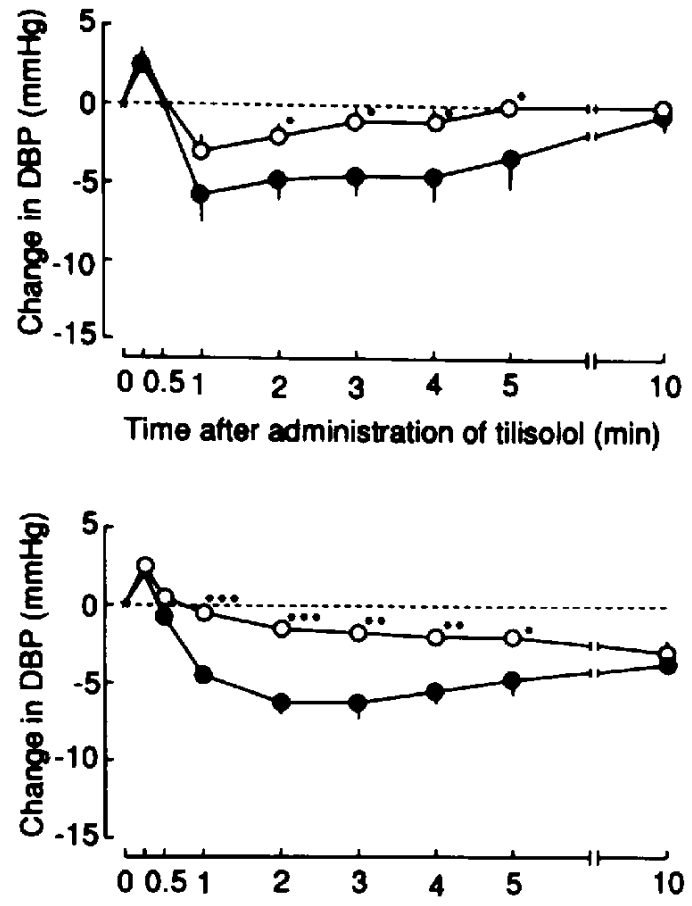

Time after administration of cromakalim (min)

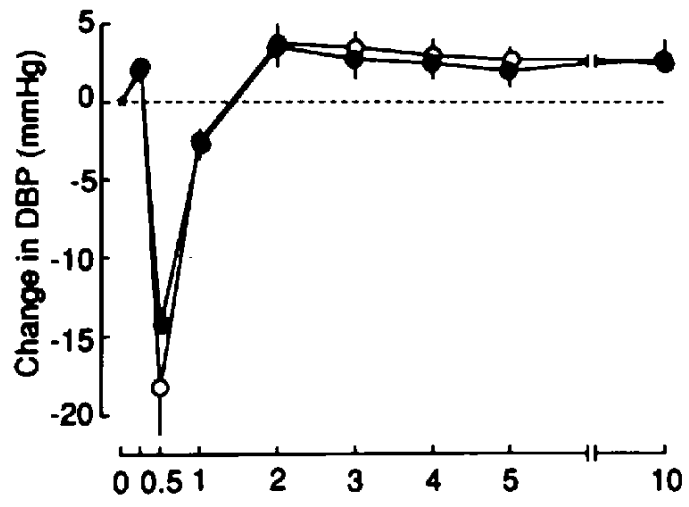

Time after administration of propranold (min)

Fig. 7. Effects of glibenclamide (10 $\mathrm{mg} / \mathrm{kg}$, i.v.) on the hypotensive responses of pithed rats to tilisolol (1.0 mg/kg, i.v.), propranolol (1.0 mg/ $\mathrm{kg}$, i.v.), and cromakalim $(0.01 \mathrm{mg} / \mathrm{kg}$, i.v.). DBP: diastolic blood pressure. Each point represents the mean \pm S.E. of 4 -6 experiments. (O) control rats, $(0)$ glibenclamidetreated rats. Initial values for the control rats were $50.5 \pm 3.3$ (tilisolol), $48.0 \pm 1.5$ (propranolol), and $47.4 \pm 1.5 \mathrm{mmHg}$ (cromakalim). Corresponding values for the glibenclamide-treatcd rats were $49.4 \pm 1.6$, $50.6 \pm 3.4$ and $49.6 \pm 1.9 \mathrm{mmHg}$, respectively. ${ }^{*} \mathrm{P}<$ $0.05,{ }^{* *} \mathrm{P}<0.01,{ }^{* * *} \mathrm{P}<0.001$. 

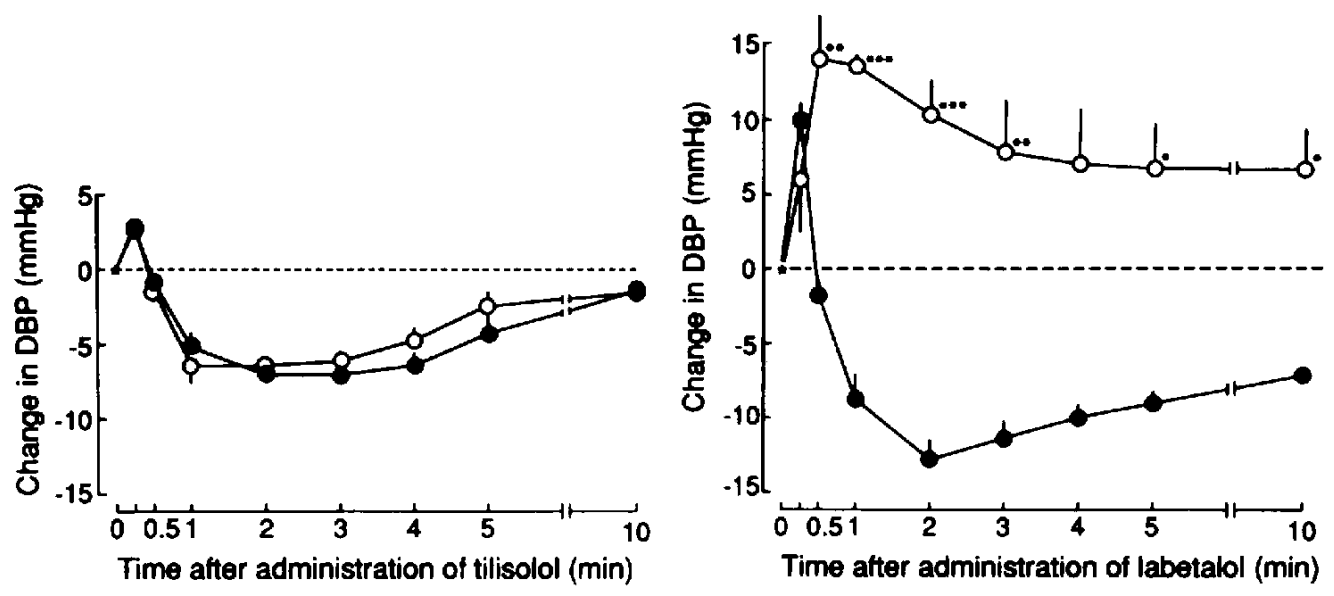

Fig. 8. Effects of nadolol (1.0 $\mathrm{mg} / \mathrm{kg}, \mathrm{i} . \mathrm{v}$.) on the hypotensive responses of pithed rats to tilisolol (1.0 $\mathrm{mg} / \mathrm{kg}, \mathrm{i.v}$ ) and labetalol $(1.0 \mathrm{mg} / \mathrm{kg}, \mathrm{i.v})$. DBP: diastolic blood pressure. Each point represents the mean \pm S.E. of 4 experiments. (O) control rats, ( $O$ ) nadolol-treated rats. Initial values for the control rats were $49.1 \pm 2.1$ (tilisolol) and $51.6 \pm 1.6 \mathrm{mmHg}$ (labetalol). Corresponding values for the nadolol-treated rats were $49.5 \pm 2.1$ and $53.1 \pm 2.2 \mathrm{mmHg}$, respectively. ${ }^{*} \mathrm{P}<0.05,{ }^{* *} \mathrm{P}<0.01,{ }^{* * *} \mathrm{P}<0.001$

glibenclamide $(10 \mathrm{mg} / \mathrm{kg})$ or DMF resulted in increases in blood pressure and heart rate, but these changes disappeared within $20 \mathrm{~min}$. At higher doses of glibenclamide $(20 \mathrm{mg} / \mathrm{kg})$, blood pressure and heart rate did not recover to control values. Therefore, we performed this experiment using a $10 \mathrm{mg} / \mathrm{kg}$ dose of glibenclamide. After a 20-min recovery period, during which the blood pressure and heart rate changes resulting from glibenclamide or DMF had returned to the control values, tilisolol $(1.0 \mathrm{mg} / \mathrm{kg})$, propranolol $(1.0$ $\mathrm{mg} / \mathrm{kg})$ or cromakalim $(0.01 \mathrm{mg} / \mathrm{kg})$ was given to the animals. Following treatment of the preparation with glibenclamide, the hypotcnsive effects of tilisolol and cromakalim were antagonized, while that of propranolol was not affected (Fig. 7).

In some experiments, the pithed rats were treated with nadolol $(1.0 \mathrm{mg} / \mathrm{kg}, \mathrm{i.v}$.$) ; and$ then after $10 \mathrm{~min}$, tilisolol $(1.0 \mathrm{mg} / \mathrm{kg})$ or labetalol $(1.0 \mathrm{mg} / \mathrm{kg})$ was injected intravenously. The hypotensive effect of labetalol was abolished and an increase in blood pressure was produced by nadolol, while that of tilisolol was not affected (Fig. 8).

\section{DISCUSSION}

In the rat thoracic aorta, tilisolol inhibited the sustained contraction elicited by $20 \mathrm{mM}$ $\mathrm{KCl}$ in a concentration-dependent manner, while nadolol and atenolol did not produce any significant inhibition of the responses to $20 \mathrm{mM} \mathrm{KCl}$. In the pithed rats, intravenous administration of tilisolol, but neither nadolol nor atenolol, caused a decrease in diastolic blood pressure. These results suggest that tilisolol caused vasodilation by direct smooth muscle relaxant effects.

In the rat thoracic aorta, tilisolol and cromakalim selectively inhibited the responses to low concentrations of $\mathrm{KCl}(10-20 \mathrm{mM})$. Propranolol, in contrast, non-competitively inhibited the responses to both low $(10-20 \mathrm{mM})$ and high concentrations of $\mathrm{KCl}(40-100 \mathrm{mM})$. Inhibition of $\mathrm{KCl}$-induced vascular contractions by cromakalim has been shown to depend on the $\mathrm{KCl}$ concentration used; the higher the $\mathrm{KCl}$ concentration, the less the inhibition $(10,15)$. Therefore, these results suggest that the vasodilator effects of tilisolol may, like those of cromakalim, be mediated by an opening of $\mathrm{K}^{+}$channels in vascular smooth 
muscle. However, in the rat thoracic aortat contracted by $20 \mathrm{mM} \mathrm{KCl}(25 \mathrm{mM} \mathrm{KCl}$ in tota), cromakalim produced about a $70.5 \%$ relaxation at its maximum effect, although tilisolol produced a full relaxation at its maximum effect. In vascular smooth muscle, nicorandil and pinacidil, now known to act like cromaka$\lim$ via $\mathrm{K}^{+}$channel opening, produce full relaxations at their maximum effects and have relaxant mechanisms of action independent of $\mathrm{K}^{+}$channel opening $(16,17)$. Therefore, additional mechanisms may be involved in the vasodilator actions of tilisolol.

It has recently been shown that glibenclamide, a potent blocker of ATP-dependent $\mathrm{K}$ channels, antagonized the vasorelaxant effect of cromakalim in vivo and in vitro $(11,12)$. It has also been shown that glibenclamide behaved as a pharmacological antagonist against $\mathrm{K}^{+}$channel openers $(18,19,13)$. Therefore, we also measured the effects of glibenclamide on the inhibitory effects of tilisolol, propranolol, and cromakalim in vitro and in vivo.

In the pithed rats, following treatment of the preparation with glibenclamide $(10 \mathrm{mg} / \mathrm{kg}$, i.v.), the hypotensive effects of tilisolol and cromakalim were antagonized, while that of propranolol was not affected. In the rat thoracic aorta, glibenclamide $\left(10^{-6} \mathrm{M}\right)$ antagonized the relaxant responses to cromakalim with a $\mathrm{pA}_{2}$ value of 7.32 , whereas it had no inhibitory action against propranolol-induced relaxation of $20 \mathrm{mM} \mathrm{KCl-induced} \mathrm{contrac-}$ tions. Glibenclamide also inhibited the ability of tilisolol to relax $20 \mathrm{mM} \mathrm{KCl}$-induced contractions. However, the antagonism by glibenclamide $\left(10^{-7}-10^{-6} \mathrm{M}\right)$ of the relaxant responses to tilisolol was not a typical competitive type, suggesting that this drug is capablc of inhibiting smooth muscle contraction by a mechanism additional to that of $\mathrm{K}^{+}$ channel opening.

These effects of tilisolol cannot be accounted for by its $\alpha$-blocking effect. Although the $\alpha$-blocking effect is observed in the isolated rat aorta with a $\mathrm{pA}_{2}$ value of 4.56 (20), it is rather difficult to explain the hypotensive effect of tilisolol in the pithed rats by its $\alpha$-blocking cffect. Prazosin, a selcctive $\alpha_{1}$ antagonist, has been reported to have little or no effect on blood pressure in the pithed rats (21). It was reported that in vascular smooth muscle preparations, cromakalim inhibited contractions elicited by norepinephrine and opening of $\mathrm{K}$ ' channels accounted for the antagonism by cromakalim of the norepinephrine-contractions $(10)$. Furthermore, tilisolol was found to have a very weak $\alpha$-blocking effect, as assessed by competitive inhibition of ${ }^{3} \mathrm{H}$-prazosin binding to membrane preparations of dog aorta and rat brain (20).

These effects also cannot be accounted for by any ISA on vascular $\beta_{2}$-receptors, since the hypotensive effect of tilisolol in the pithed rats was not affected by nadolol treatment. The hypotensive effect of labetalol was abolished and an increase in blood pressure was produced by treatment with nadolol. It has been reported by Nakagawa et al. (22) that labetalol had an ISA on $\beta$-receptors and vascular $\alpha_{1}$-receptors. Therefore, in the presence of nadolol, the hypotension by $\beta_{2}$ ISA may be suppressed and the hypertension by $\alpha_{1}$ ISA may be produced.

These results suggest that the vasorelaxant and hypotensive actions of tilisolol seem to result from an opening of $\mathrm{K}^{\dagger}$ channels which can be inhibited by glibenclamide and an unidentified mechanism which can not be inhibited by glibenclamide.

\section{REFERENCES}

1 Nadelmann, J. and Frishman, W.H.: Clinical use of $\beta$-adrenoceptor blockade in systemic hypertension. Drugs 39, 862-876 (1990)

2 Vanzwieten, P.A.: Pharmacology of antihypertensive agents with multiple actions. Eur. J. Clin. Pharmacol. 38, S77-S81 (1990)

3 Suzuki, Y., Sugai, T, and Kobayashi, A.: A new potent beta-adrenergic blocking agent, N-696 (Abstract). In Eighth International Congress of Pharmacology, Tokyo, p. 382 (1981)

4 Nakagawa, Y., Sugai, T., Chin, W.-P., Shibuya. T., Hashimoto, K. and Imai, S.: Pharmacological profile of a new $\beta$-adrenoceptor blocker, 4-(3(tert-butylamino)-2-hydroxypropoxy)-N-methylisocarbostyril hydrochloride (N-696). Arzneimittel 
forschung 34, 194- 199 (1984)

5 Tsukiyama, H., Otsuka, K., Takasaki, I. and Horii, M.: Hemodynamic effects of dilevalol and $\mathrm{N}-696$, new $\beta$-blocking agents with vasodilating properties, and doxazosin and urapidil, ncw $\alpha$ blocking agents, in essential hypertension. J. Cardiovasc. Pharmacol. 11, Supp. 2, S32-S35 (1988)

6 Imaizumi, T., Takeshita, A., Nakamura, N., Hirooka, Y., Suzuki, S., Yoshida, M. and Nakamura, M.: Vasodilating effect of the new $\beta$-blocker tilisolol hydrochloride in humans. Arzncimittelforschung 38, $1342-1344$ (1988)

7 Cook, N.S.: The pharmacology of potassium channels and their therapeutic potential. Trends Pharmacol. Sci. 9, 21-28 (1988)

8 Hamilton, T.C., Weir, S.W. and Weston, A.H.: Comparison of the effects of BRL 34915 and verapamil on electrical and mechanical activity in rat portal vein. Br. J. Pharmacol. 88, 103-111 (1986)

9 Quast, U.: Effect of the $\mathrm{K}^{+}$efflux stimulating vasodilator BRL 34915 on ${ }^{86} \mathrm{Rb}^{+}$efflux and spontaneous activity in guinea-pig portal vein. Br. J. Pharmacol. 91, 569-578 (1987)

10 Weir, S.W. and Weston, A.H.: The effects of BRL 34915 and nicorandil on electrical and mechanical activity and on ${ }^{86} \mathrm{Rb}$ efflux in rat blood vessels. Br. J. Pharmacol. 88, 121-128 (1986)

11 Cavero, I., Mondot, S., Mestre, M. and Escande, D.: Hacmodynamic and pharmacological mechanism of the hypotensive effects of cromakalim in rats: Blockade by glibenclamide. Br. J. Pharmacol. 95.643P (1988)

12 Buckingham, R.E., Hamilton, T.C., Howlett, D.R., Mootoo, S. and Wilson, C.: Inhibition by glibenclamide of the vasorclaxant action of cromakalim in the rat. Br. J. Pharmacol. 97, 57-64 (1989)

13 Yamada, H., Yoneyama, F., Satoh, K. and Taira, N.: Specific but differential antagonism by glibenclamide of the vasodepressor effects of cromakalim and nicorandil in spinally-anaesthetized dogs. Br. J. Pharmacol. 100, $413-416$ (1990)

14 Gillespie, J.S., Maclaren, A. and Pollock, D.: A method of stimulating different segments of the autonomic outflow from the spinal column to various organs in the pithed cat and rat. Br. J. Pharmacol. 40, $257-267$ (1970)

15 Cook, N.S., Quast, U., Hof, R.P., Baumlin, Y. and Pally, $C$.: Similaritics in the mechanism of action of two new vasodilator drugs: pinacidil and BRL 34915. J. Cardiovasc. Pharmacol. 11, 90-99 (1988)

16 Wilson, C., Coldwell, M.C., Howlett, D.R., Cooper, S.M. and Hamilton, T.C.: Comparative effects of $\mathrm{K}^{+}$channel blockade on the vasorelaxant activity of cromakalim, pinacidil and nicorandil. Eur. J. Pharmacol. 152, 331 - 339 (1988)

17 Satoh, K., Yamada, H. and Taira, N.: Differential antagonism by glibenclamide of the relaxant effects of cromakalim, pinacidil and nicorandil on canine large coronary arteries. Naunyn Schmiedebergs Arch. Pharmacol. 343, 76-82 (1991)

18 Winquist, R.J., Heaney, L.A., Wallace, A.A., Baskin, E.P., Stein, R.B., Garcia, M.L. and Kaczorowski, G.J.: Glyburide blocks the relaxation response to BRL 34915 (cromakalim), minoxidil sulfate and diazoxide in vascular smooth muscle. J. Pharmacol. Exp. Ther. 248, $149-156$ (1989)

19 Quast, U. and Cook, N.S.: In vitro and in vivo comparison of two $\mathrm{K}^{+}$channel openers, diazoxide and cromakalim, and their inhibition by glibenclamide. J. Pharmacol. Exp. Ther. 250, 261-271 (1989)

20 Nagatomo, T., Tsuchihashi, H., Sasaki, S. . Nakagawa, Y., Nakahara, H. and Imai, S.: Displacement by $\alpha$-adrenergic agonists and antagonists of ${ }^{3} \mathrm{H}$-prazosin bound to the $a$-adrenoceptors of the dog aorta and the rat brain. Japan. J. Pharmacol. 37. $181-187$ (1985)

21 Hirohashi, M., Tamura, K. and Akashi, A.: Intrinsic pressor activity of midaglizole, an alpha-2 adrenoceptor antagonist, in pithed rats. Japan. J. Pharmacol. 53, $519-520$ (1990)

22 Nakagawa, Y., Nakahara, H., Chin, W.-P. and Imai, S.: Blockade and vasodilation induced by nipradilol, arotinolol and labetalol in pithed rats. Japan. J. Pharmacol. 39, 481-485 (1985) 